\title{
Influences Of Internal Environment, External Environment, Business Ethics And Entrepreneurship Toward Business Performances Through Differentiation Strategies And Competing Superiorities In Small Industries In Surabaya City
}

\author{
Jaya Adi Gama Tengtarto \\ Doctoral student, Faculty of Economics and Business, \\ University of 17 Agustus 1945, Surabaya, Indonesia
}

\author{
Tri Ratnawati \\ Lecturer of Accounting Department, Faculty of Economics and Business, \\ University of 17 Agustus 1945, Surabaya, Indonesia \\ Amiartuti Kusmaningtyas \\ Lecturer of Human Capital Department, Faculty of Economics and Business, \\ University of 17 Agustus 1945, Surabaya, Indonesia
}

\begin{abstract}
The purpose of this study is to examine and analyze the influence of: (1) internal environment, external environment, business ethics, entrepreneurial orientation on differentiation strategies; (2) internal environment, external environment, business ethics, entrepreneurial orientation, differentiation strategies on competitive advantage; (3) internal environment, external environment, business ethics, entrepreneurial orientation, differentiation strategies, competitive advantage on business performance. This research is an explanatory type of research with a quantitative approach. The populations in this study were all Small Industries in Surabaya as many as $\mathbf{3 8 4}$ Small Industries in Surabaya, while the samples used were 349 Small Industries in Surabaya. Data collection is done by questionnaire. The data analysis technique used is the Structural Equation Model (SEM) with AMOS program. Based on the results of the analysis shows that: (1) internal environment, external environment, business ethics, entrepreneurial orientation significantly influences on differentiation strategy; (2) business ethics, entrepreneurial orientation, differentiation strategy has a significant influences on competitive advantage, while internal environment and external environment does not have a significant influences on competitive advantage; (3) internal environment, entrepreneurial orientation, differentiation strategies, competitive advantage has a significant influences on the performance of small industries, while external environment and business ethics has no significant influences on the performance of small industries.
\end{abstract}

Keywords : Internal Environment, External Environment, Business Ethics, Entrepreneurial Orientation, Differentiation Strategies, Competitive Advantage, Performance of Small Industries.

\section{INTRODUCTION}

The existence of Small Industries in Indonesia today continues increasing and developing rapidly. Besides that, Small Industries are proved to be able to endure and continually develop in the middle of crisis, because generally, these sectors still use local resources, both resources of human, capitals, raw materials, and tools, it means most of Small Industry needs do not depend on import items. Small Industries are crucial Indonesian economical supporters. In the 
middle of weakening global economics that strikes Indonesia today, Small Industries are hardly influenced and the growths are relatively stable (Gunawan, 2016).

According to the data of Industrial Ministry in 2016, Small Industries in Indonesia grew into 165,983 units by the total Small Industrial centers as 7,437 centers or they increased 4.5 percents compared with in 2015 and they have absorbed employees as 350,000 people. Statistical Center Office noted, the small industrial growths along 2017 were in the number of 4.74 percents. The growths were the lowest since 2013 ago, in which in 2013, small industries had chances to grow 7.51 percents, then they decreased in 2015 as 5.71 percents, and they returned to increase in 2016 but only as 5.78 percents (Gumelar, 2018). However, small industries in East Java slightly showed significant development, seen from decreases from 2013 as 89,786 units to be 39,932 units in 2014 and they increased in 2015 but insignificantly.

Majority of Small Industries will be able to endure and develop by having conducive internal and external environments. Improvement of small industrial performances is not separated from the abilities of facing environmental changes. Crijns and Ooghi (2000) explained that each company growth step is the result from two environments in which company does the business, i.e. internal and external environment. The research results conducted by Nurlina cs (2013) researched internal environmental influences toward differentiation strategies in Ornamental Plant Micro Business in Denpasar City and the results show that there are influences of internal environmental variables toward differentiation strategies. The research of Setyowati (2015) showed that internal environment influences significantly toward competing superiorities. Handriani (2011) proved that there are positive influences from internal variables toward competitiveness of Small and Medium Enterprises in Semarang Regency. Therefore, if internal conditions in Small and Mediun Enterprises are good, so it will improve competitiveness of Small and Medium Enterprises. However, it is slightly different with the research findings of Nurlina cs (2013) that concluded that internal environment does not have direct influences toward competing superiorities.

Other factor that can support Small Industrial existence is business ethics. This case is proper with the opinion of Hafsah (2003) that business partnership successes are considerably determined by obediences among the ones partnered in running the business ethics. Today, there are still many companies that do not care about ethical problems in the business activities. This case also become problems for Small Industries in Surabaya in which business ethics is valued as still insufficient. Ethics is very important for company in running the business (Sinaulan, 2016). Ethics in business must be maintained by company in running the business. If the company still maintains the ethics in doing processes of productions and selling the products, so the products sold will be accepted by consumers as the final parties who buy or consume the products (Sinaulan, 2016).

Entrepreneurship orientation is also seen as necessary in supporting small industrial existence. According to the opinion of Kuncoro (2006) small industries in Indonesia is in quality difficult to develop in markets becayse facing several internal problems, one of them is less entrepreneurship orientation. The research of Thibault (2001) expressed the important relations between entrepreneur characters and business characters toward performances and business growths in small industries. The research results of Sinaga cs (2016) found entrepreneurship orientation toward company performances. If internal environment and external environment, business ethics, and entrepreneurship orientation are in small industries, so it is hoped that they can run differentiation strategies. Small industries that can run differentiation strategies, so they will be also able to be superior in competing. Small industries that have superiorities in competing, so the small industrial performances are also 
hoped to improve. This case is proper with the opinion of Porter (2008) who explained that competing superiorities are performance hearts for facing competitions. The same one is expressed by the statement of Ferdinand (2003) who explained that in competing markets, company abilities in resulting performances considerably depend on the competing superiority degrees.

Small industries that have differentiation strategies are also hoped to have improving performances. This case is proper with the opinion of Porter (2008) who explained that there are 3 strategies in some company, they are strategies of differentiation, cost leadership, and focus. Differentiation strategy is strategy for winning competition by developing product/service uniquenesses offered (Porter, 2008). The research results conducted by Anggraini and Sukaatmadja (2015) who researched in culinary industry in Denpasar City, the results prove that differentiation strategies influence positively and significantly toward culinary industrial performance improvement in Denpasar City. This case shows that differentiation strategy applications in culinary industries can improve the company performances.

It can be said that differentiation strategies are very important for competing superiorities, such as Kotler (2008) who stated that competing superiorities of a company is by company offer differentiation that will give more values to consumers than the brought by competitors. The research results conducted by Ramadhani (2012) showed that overall differentiation strategies influence significantly toward competitiveness improvement. So did Sulistiani (2014) who stated that differentiation strategies influence significantly toward competing superiorities of some company.

\section{Theoretical Basis}

\section{LITERATURE REVIEWS}

\section{Strategy Management}

Strategy managemental definition by Wheelen and Hunger (2008:3) was defined as a set of managerial decisions and actions that determine long-term performances from company. This involves environmental scanner [both external and internal], strategy formulation [strategy or long-term plan], strategy control execution and evaluation.

\section{Internal Environment}

According to Coulthard (2007:31) internal environment could be defined as relationship dynamism that has moderating and mediating roles in organizational components such as cultures, strategies, leadership, processes of taking decisions, structures, and resources. Internal environment can be measured through several indicators that refer to Wulandari (2009) they are: (1) Company measure; (2) Organizational structure; (3) Company strategy; (4) Making process; (5) Business strategy; (6) Company resources; (7) Company culture; (8) Managemental team characteristics.

\section{External Environment}

Pearce and Robinson (2013:92), explained that company external environments are all conditions and strengths that influence strategic options conducted by company and determine the competition situations. External environment can be measured through several indicators that refer to Wulandari (2009) they are: (1) Dynamism; (2) Munificence; (3) Complexity; (4) Characteristic. 


\section{Business Ethics}

According to Muslich (2009:9) business ethics can be meant as knowledge about ideal procedures of ruling and managing business that care about valid norms and moralities universally and economically/socially, and applying these norms and moralities support business activity aims and purposes. Business ethics in this research is measured through several indicators that refer to Muslich (2009), they are: (1) Economical principles; (2) Honesty principles; (3) Good intention principles and Not having evil intentions; (4) Fair principles; (5) Respecting principles to yourself

\section{Entrepreneurship Orientation}

Entrepreneurship orientation is some organizational phenomenon that reflects their managerial abilities, as company begins to do initiative and change competitive actions so it can prosper the business run (Quantananda and Haryadi, 2015:707). Entrepreneurship orientation in this research is measured through several indicators that refer to Zimmerer and Scarborugh (2008), they are: (1) Innovative; (2) Proactive; (3) Courage in taking risks.

\section{Differentiation Strategy}

According to Pearce and Robinson (2013:4) strategy is company plan for creating competing superiorities. Differentiation strategy is strategy used by company for differentiating products sold and competitor products in order to be known by consumers. Differentiation strategy in this research is measured through several indicator that refer to Porter in Ingga (2009), they are: (1) Product quality; (2) Service quality; (3) Advertisement; (4) R\&D activities; (5) Price; (6) Time of delivering items; (7) Guaranteed stocks; (8) Product designs are more interesting; (9) After sales service

\section{Competing Superiority}

Competing superiority is development from the values that can be created by company for the buyers (Ramadhani, 2012:4). Competing superiority is business ability for achieving abnormal profits in industrial competitions through strategies of creating values. Competing superiority in this research is measured through several indicators that refer to Thomson, et al (2010:163), they are: (1) Determining the lowest costs; (2) Differentiation; (3) Determining the best costs; (4) Differentiation focus; (5) low cost strategy focus.

\section{Small Industry Performance}

According to Mulyadi (2011:337), performance is success of organizational personnel, team, or unit in forming strategic targets that have been determined before by the hoped attitudes. Small Industry Performance is something resulted by some Small Industry in certain period by referring to the determined standards. Small Industry Performance in this research is measured through several indicators that refer to Munizu (2010), they are: (1) Sales Growth; (2) Capital Growth; (3) Employee Growth; (4) Market Growth; (5) Profit Growth. 


\section{Conceptual Model}

Figure 1. Conceptual Model

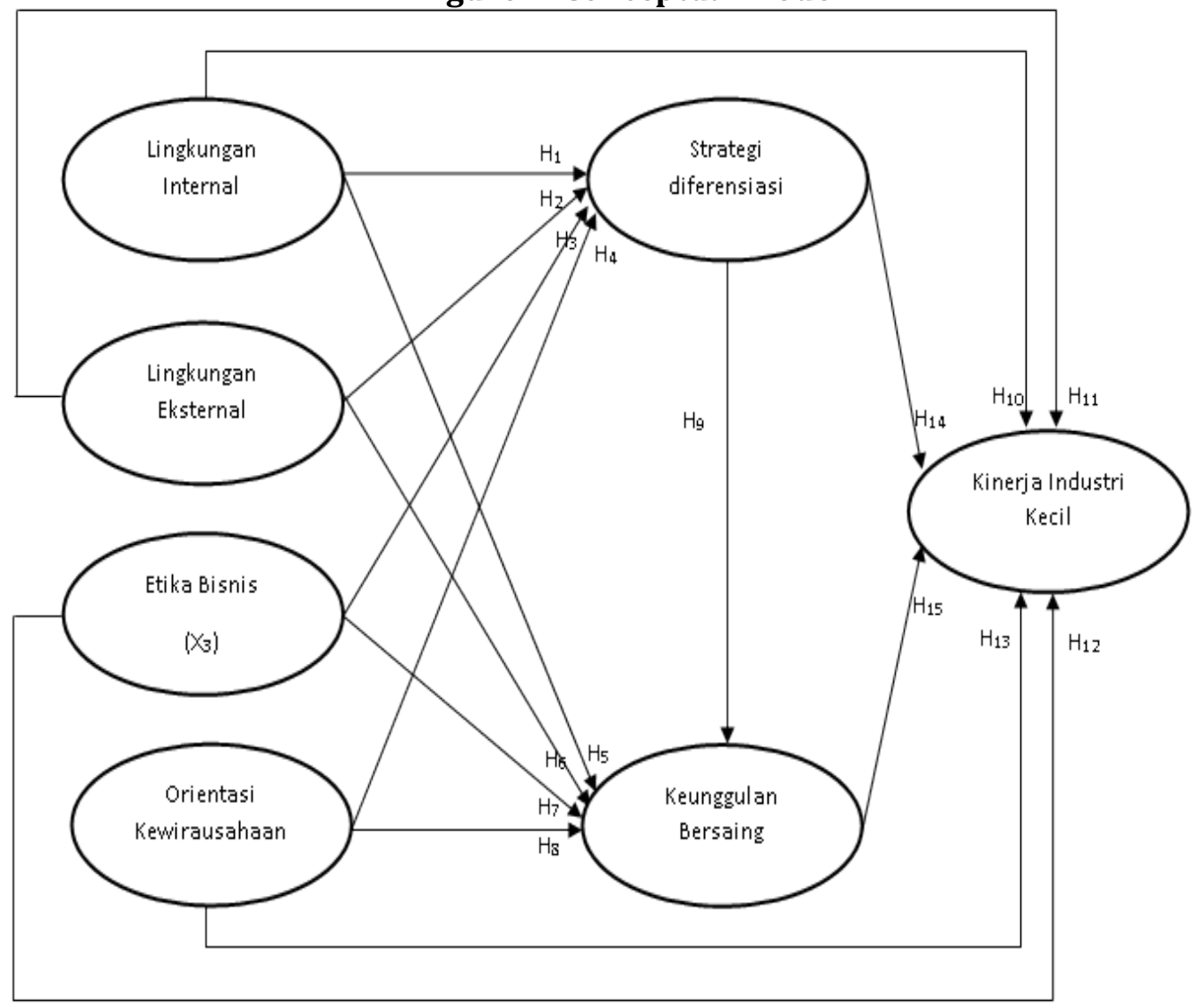

\section{Research Hypothesis}

$\mathrm{H}_{1}$ : Internal environment influences toward differentiation strategies in small industries in Surabaya City.

$\mathrm{H}_{2}$ : External environment influences toward differentiation strategies in small industries in Surabaya City.

$\mathrm{H}_{3}$ : Business ethics influences toward differentiation strategies in small industries in Surabaya City.

$\mathrm{H}_{4}$ : Entrepreneurship orientation influences toward differentiation strategies in small industries in Surabaya City.

$\mathrm{H}_{5}$ : Internal environment influences toward competing superiorities in small industries in Surabaya City.

$\mathrm{H}_{6}$ : External environment influences toward competing superiorities in small industries in Surabaya City.

$\mathrm{H}_{7}$ : Business ethics influences toward competing superiorities in small industries in Surabaya City.

$\mathrm{H}_{8}$ : Entrepreneurship orientation influences toward competing superiorities in small industries in Surabaya City.

$\mathrm{H}_{9}$ : Differentiation strategies influence toward competing superiorities in small industries in Surabaya City.

$\mathrm{H}_{10}$ : Internal environment influences toward small industry performances in small industries in Surabaya City.

$\mathrm{H}_{11}$ : External environment influences toward small industry performances in Surabaya City. 
$\mathrm{H}_{12}$ : Business ethics influences toward small industry performances in Surabaya City.

$\mathrm{H}_{13}$ : Entrepreneurship orientation influences toward small industry performances in Surabaya City.

$\mathrm{H}_{14}$ : Differentiation strategies influence toward small industry performances in Surabaya City.

$\mathrm{H}_{15}$ : Competing superiorities influence toward small industry performances in Surabaya City.

\section{RESEARCH METHODS}

This research is quantitative research by the research type based on observational time, i.e. crossectional study. The utility type from the research includes explanation research type or Explanatory Study.

The population in this research consists of all small industries in Surabaya that have investment values below 1 billions as 384 small industries in Surabaya. The sample-taking technique taken is surfeited sampling technique. The samples in this research are 384 small industries in Surabaya. But in the questionnaire distribution processes, there are 16 questionnaires that are not returned and lost anad also 19 questionnaires are incomplete in filling answers in the questionnaires, so the samples that can be used in this research are 349 small industries in Surabaya.

The analysis technique chosen for analyzing data and examining hypothesis in this research is Structural Equation Model (SEM) by the program aid of AMOS (Analysis of Moment Strucures).

\section{Structural Similarity}

\section{RESEARCH RESULTS}

Structural similarity is function or model of causality relation among the variables researched and hypothesized. This research shows that there are three endogenous variables and four exogenous variables. From the SEM analysis results by AMOS, it is achieved the two research similarities, they are:

Differentiation Strategies $Z_{1}=0.347$ Internal Environment $X_{1}+0.415$ External Environment $X_{2}$ + 0.110 Business Ethics $\mathrm{X}_{3}+0.077$ Entrepreneurship Orientation $\mathrm{X}_{4}$

Competing Superiorities $\mathrm{Z}_{2}=0.055$ Internal Environment $\mathrm{X}_{1}-0.013$ External Environment $\mathrm{X}_{2}$ +0.324 Business Ethics $X_{3}+0.465$ Entrepreneurship Orientation $X_{4}+0.187$ Differentiation Strategies $\mathrm{Z}_{1}$

Small Industry Performances $Y=0.114$ Internal Environment $X_{1}+0.102$ External Environment $\mathrm{X}_{2}+0.064$ Business Ethics $\mathrm{X}_{3}+0.135$ Entrepreneurship Orientation $\mathrm{X}_{4}+0.202$ Differentiation Strategies $\mathrm{Z}_{1}+0.452$ Competing Superiorities $\mathrm{Z}_{2}$

\section{Hypothesis Examination Results}

The research hypothesis examination is conducted based on the causality relational analysis results inter-research constructs, as served in the following Table 1: 
Table 1

Direct Influence Examinational Results of Research Hypothesis

\begin{tabular}{|c|c|c|c|c|c|}
\hline No. & & Estimate & CR & P value & Decision \\
\hline 1 & $\begin{array}{l}\text { Internal Environment } \mathrm{X}_{1} \rightarrow \\
\text { Differentiation Strategies } \mathrm{Z}_{1}\end{array}$ & 0.347 & 8.331 & 0.000 & Significant \\
\hline 2 & $\begin{array}{l}\text { External Environment } \mathrm{X}_{2} \rightarrow \\
\text { Differentiation Strategies } \mathrm{Z}_{1}\end{array}$ & 0.415 & 9.547 & 0.000 & Significant \\
\hline 3 & $\begin{array}{c}\text { Business Ethics } \mathrm{X}_{3} \rightarrow \\
\text { Differentiation Strategies } \mathrm{Z}_{1}\end{array}$ & 0.110 & 2.761 & 0.006 & Significant \\
\hline 4 & $\begin{array}{c}\text { Entrepreneurship Orientation } \mathrm{X}_{4} \\
\rightarrow \text { Differentiation Strategies } \mathrm{Z}_{1}\end{array}$ & 0.077 & 1.995 & 0.046 & Significant \\
\hline 5 & $\begin{array}{l}\text { Internal Environment } X_{1} \rightarrow \\
\text { Competing Superiorities } Z_{2}\end{array}$ & 0.055 & 1.055 & 0.291 & Not Significant \\
\hline 6 & $\begin{array}{l}\text { External Environment } \mathrm{X}_{2} \rightarrow \\
\text { Competing Superiorities } \mathrm{Z}_{2}\end{array}$ & -0.013 & -0.228 & 0.819 & Not Significant \\
\hline 7 & $\begin{array}{c}\text { Business Ethics } \mathrm{X}_{3} \rightarrow \text { Competing } \\
\text { Superiorities } \mathrm{Z}_{2} \\
\end{array}$ & 0.324 & 6.629 & 0.000 & Significant \\
\hline 8 & $\begin{array}{l}\text { Entrepreneurship Orientation } \mathrm{X}_{4} \\
\rightarrow \text { Competing Superiorities } \mathrm{Z}_{2}\end{array}$ & 0.465 & 9.324 & 0.000 & Significant \\
\hline 9 & $\begin{array}{c}\text { Differentiation Strategies } \mathrm{Z}_{1} \rightarrow \\
\text { Competing Superiorities } \mathrm{Z}_{2}\end{array}$ & 0.187 & 2.357 & 0.018 & Significant \\
\hline 10 & $\begin{array}{c}\text { Internal Environment } \mathrm{X}_{1} \rightarrow \text { Small } \\
\text { Industry Performances Y }\end{array}$ & 0.114 & 1.981 & 0.048 & Significant \\
\hline 11 & $\begin{array}{c}\text { External Environment } \mathrm{X}_{2} \rightarrow \text { Small } \\
\text { Industry Performances } \mathrm{Y}\end{array}$ & 0.102 & 1.627 & 0.104 & Not Significant \\
\hline 12 & $\begin{array}{l}\text { Business Ethics } \mathrm{X}_{3} \rightarrow \text { Small } \\
\text { Industry Performances } \mathrm{Y}\end{array}$ & 0.064 & 1.101 & 0.271 & Not Significant \\
\hline 13 & $\begin{array}{l}\text { Entrepreneurship Orientation } \mathrm{X}_{4} \\
\rightarrow \text { Small Industry Performances Y }\end{array}$ & 0.135 & 2.158 & 0.031 & Significant \\
\hline 14 & $\begin{array}{l}\text { Differentiation Strategies } \mathrm{Z}_{1} \rightarrow \\
\text { Small Industry Performances } \mathrm{Y}\end{array}$ & 0.202 & 2.293 & 0.022 & Significant \\
\hline 15 & $\begin{array}{l}\text { Competing Superiorities } \mathrm{Z}_{2} \rightarrow \\
\text { Small Industry Performances } \mathrm{Y}\end{array}$ & 0.452 & 5.480 & 0.000 & Significant \\
\hline
\end{tabular}

\section{Criteria Evaluational Results of Goodness of Fit}

After SEM assumptions are fulfilled, so it is conducted structural fairness examination and therefore, it will be used several model fairness indexes in which the results are seen in the following Table 2:

Table 2

Criteria Evaluation of Goodness of Fit Indices

\begin{tabular}{|c|c|c|c|}
\hline Criteria & Result & Cut-off Value & Model Evaluation \\
\hline Chi-Square & 829.57 & It is hoped the value is small & Fit \\
\hline Probability & 0.586 & $>0.05$ & Fit \\
\hline Cmin/DF & 0.989 & $<2$ & Fit \\
\hline RMSEA & 0.000 & $<0.08$ & Fit \\
\hline AGFI & 0.891 & $0.80-0.90$ & Fit \\
\hline GFI & 0.903 & $0.80-0.90$ & Fit \\
\hline CFI & 1.000 & $>0.90$ & Fit \\
\hline TLI & 1.001 & $>0.90$ & Fit \\
\hline
\end{tabular}

The probability value as 0.586 means $>0.05$ by fit category. The value of Cmin/DF as 0.989 means $<2$ by fit category. The value of RMSEA as 0.000 means $<0.08$ by fit category. AGFI as 0.891 means close to this value between 0.80 to 0.90 by fit category. The value of GFI as 0.903 means between the value of 0.80 and 0.90 by fit category. The value of CFI as 1.000 means > 
0.90 by fit category. The value of TLI as 1.001 means $>0.90$ by fit category. Based on table 5.20, it can be explained that the examinational results of goodness of fit in structural similarity model show the good data because they have met all criteria required.

\section{DISCUSSIONS}

\section{Internal Environmental Influences to Differentiation Strategies}

Based on the research results, so the finding in this research is internal environment has significant influences toward differentiation strategies. This case can be seen from the value of CR as 8.331, by p value as 0.000 or less than 0.05 , it means that differentiation strategies can be formed by good internal environment. This case means that the hypothesis that sounds "Internal environment influences toward differentiation strategies in small industries in Surabaya City" is accepted. The relations of internal environmental and differentiation strategy variables are positive, so it can be said that the better the internal environment created by small industries in Surabaya, so it will be better and better in creating differentiation strategies. According to Nurlina cs (2013) through internal environmental mastery and control by prioritizing production resources supported by human resources abilities, so differentiation strategy application from business doers becomes proper and proper for responding chances and challenges faced. The results in this research are parallel with the research findings of Syafarudin (2015) who stated that internal environment influences significantly toward differentiation strategies.

\section{External Environmental Influences Toward Differentiation Strategies}

Based on the research results, so the finding in this research is external environment has significant influences toward differentiation strategies. This case can be seen from the value of CR as 9.547 , by p value as 0.000 or less than 0.05 , it means that differentiation strategies can be influenced by creating good external environment but the influences are not significant. This case means that the hypothesis that sounds "External environment influences toward differentiation strategies in small industries in Surabaya City" is accepted. The relations of external environment and differentiation strategy variables are positive, so it can be said that the better the external environment created around the small industry doer environment, so it will be better and better the differentiation strategies created by small industries in Surabaya. The findings are consistent with the research results of Ingga (2009) in which external environment influences positively and significantly toward differentiation strategies.

\section{Business Ethical Influences Toward Differentiation Strategies}

Based on the research results, so the finding in this research is business ethics has significant influences toward differentiation strategies. This case can be seen from the value of CR as 2.761 , by $p$ value as 0.006 or less than 0.05 , it means that differentiation strategies can be influenced by good business ethical applications in running the business. This case means that the hypothesis that sounds "Business ethics influences toward differentiation strategies in small industries in Surabaya City" is accepted. The relations of business ethical and differentiation strategy variables are positive, so it can be said that the better the business ethics owned by small industries in Surabaya, so it will be better and better the differentiation strategies created by small industries in Surabaya. The business ethics aimed is business managemental attitude by caring about valid norms and moralities.

\section{Entrepreneurship Orientation Influences Toward Differentiation Strategies}

Based on the research results, so the finding in this research is entrepreneurship has significant influences toward differentiation strategies. This case can be seen from the value of CR as 1.995 , by $p$ value as 0.046 or less than 0.05 , it means that differentiation strategies can be influenced by abilities in good entrepreneurship orientation. This case means that the 
Tengtarto, J. A. G., Ratnawati, T., \& Kusmaningtyas, A. (2020). Influences Of Internal Environment, External Environment, Business Ethics And Entrepreneurship Toward Business Performances Through Differentiation Strategies And Competing Superiorities In Small Industries In Surabaya City. Archives of Business Research, 8(1), 138-151.

hypothesis that sounds "Entrepreneurship orientation influences toward differentiation strategies in small industries in Surabaya City" is accepted. The influences of entrepreneurship orientation toward differentiation strategy variables are positive, so it can be said that the higher the entrepreneurship orientation owned by small industries in Surabaya, so it will be higher and higher the differentiation strategies created by small industries in Surabaya. Nuvriasari cs (2015) showed that there are positive and significant influences between entrepreneurship orientation and competing strategies [differentiation strategies, low costs, and focuses).

\section{Internal Environmental Influences Toward Competing Superiorities}

Based on the research results, so the finding in this research is internal environment does not have significant influences toward competing superiorities. This case can be seen from the value of $\mathrm{CR}$ as 1.055 , by $\mathrm{p}$ value as 0.291 or more than 0.05 , it means that competing superiorities can be improved by good internal environment, but the improvement is not significant. This case means that the hypothesis that sounds "Internal environment influences toward competing superiorities in small industries in Surabaya City" is unaccepted. Internal environment influences insignificantly toward competing superiorities but it has positive relational directions, so it can be said that the better the internal environment created by small industries in Surabaya, so it will be higher and higher the competing superiorities in running the business. The research results are parallel with the research results of Ingga (2009), that showed that internal environment does not influence significantly toward competitive superiorities. But, the findings do not support the findings of Setyowati (2015) that proved that internal environment influences significantly toward competing superiorities.

\section{External Environmental Influences toward Competing Superiorities}

Based on the research results, so the finding in this research is external environment does not have significant influences toward competing superiorities. This case can be seen from the value of $C R$ as -0.228 , by $p$ value as 0.819 or less than 0.05 , it means that competing superiorities can be improved through good external environment but the improvement is not significant. This case means that the hypothesis that sounds "External environment influences toward competing superiorities in small industries in Surabaya City is unaccepted. Nurlina cs (2013) said that external environment can improve competing superiorities directly, this case is parallel with the opinion of Crijns and Ooghi (2000:56) that the higher the company abilities for managing internal environment, so the company tends to be more and more proactive in seeking new chances, it will be more innovative and creative than the competitors, respond the happening changes in external environment well, bravely take risks and have authorities for running the company decisions.

\section{Business Ethical Influences toward Competing Superiorities}

Based on the research results, so the finding in this research is business ethics has significant influences toward competing superiorities. This case can be seen from the value of CR as 6.629 by $\mathrm{p}$ value as 0.000 or less than 0.05 , it means that competing superiorities can be formed by good business ethical applications. This case means that the hypothesis that sounds "Business ethics influences toward competing superiorities in small industries in Surabaya City" is accepted. The variable relations of business ethics and competing superiorities are positive, so it can be said that the better the business ethics owned by small industries in Surabaya, so it will be higher and higher the competing superiorities in managing the business. The research results are parallel with the research results of Mariadji and Yuniati (2014) in which business ethics has significant influences toward competitive superiorities. 


\section{Entrepreneurship Orientation Influence Toward Competing Superiorities}

Based on the research results, so the finding in this research is entrepreneurship orientation has significant influences toward competing superiorities. This case can be seen from the value of CR as 9.324 , by $\mathrm{p}$ value as 0.000 or less than 0.05 , it means that competing superiorities can be influenced by good entrepreneurship orientation. This case means that the hypothesis that sounds "Entrepreneurship orientation influences toward competing superiorities in small industries in Surabaya City is accepted. The variable relations of entrepreneurship orientation and competing superiorities are positive, so it can be said that the better the entrepreneurship orientation owned by small industries in Surabaya, so it will give and give impacts in competing superiority improvement in running the business. An entrepreneur who runs entrepreneurship orientation has attitudes of innovative, proactive and bravely taking risks. The research results are parallel with the research results of Sinaga, Mangunwiharjo, and Sugiarto (2016) in which in the research was found that entrepreneurship orientation has positive and significant influences toward competing superiorities.

\section{Differentiation Strategy Influences toward Competing Superiorities}

Based on the research results, so the finding in this research is differentiation strategy has significant influences toward competing superiorities. This case can be seen from the value of CR as 2.357 , by $p$ value as 0.018 or less than 0.05 , it means that competing superiorities can be formed by good differentiation strategies. This case means that the hypothesis that sounds "Differentiation strategies influences toward competing superiorities in small industries in Surabaya City" is accepted. The variable relations of differentiation strategies and competing superiorities are positive, so it can be said that the higher the differentiation strategies created by small industries in Surabaya, so it will improve and improve competing superiorities in running the business. Differentiation superiorities become one of unique aspects in some organization that influences consumer targets to be loyal consumers of the company compared with other competitors (Ramadhani, 2012). The research results support the findings of Nurlina cs (2013) who found significant influences between differentiation strategies and competing superiorities.

\section{Internal Environmental Influences toward Small Industrial Performances}

Based on the research results, so the finding in this research is internal environment has significant influences toward small industrial performances. This case can be seen from the value of $C R$ as 1.981 , by $p$ value as 0.048 or less than 0.05 , it means that small industry performances can be formed by good internal environment. This case means that the hypothesis that sounds "Internal environment influences toward small industry performances in small industries in Surabaya City" is accepted. The happening influences between the variables of internal enviroment and small industrial performances are positive, so it can be said if some small industries have and have good internal environments, so the higher the small industrial performances in Surabaya. The research results support the research results of Sumantri cs (2013) who showed that internal environment influeces positively and significantly toward business performances.

\section{External Environmental Influences toward Small Industrial Performances}

Based on the research results, so the finding in this research is external environment does not have significant influences toward differentiation strategies. This case can be seen from the value of $C R$ as 1.627 , by $p$ value as 0.104 or more than 0.05 , it means that small industrial performances can be improved by good external environment but the improvement is not significant. This case means that the hypothesis that sounds "External environment influences toward small industrial performances in Surabaya City" is unaccepted. Riyanto (2010) expressed that if external environment changes so it will cause Small and Medium Enterprises 
Tengtarto, J. A. G., Ratnawati, T., \& Kusmaningtyas, A. (2020). Influences Of Internal Environment, External Environment, Business Ethics And Entrepreneurship Toward Business Performances Through Differentiation Strategies And Competing Superiorities In Small Industries In Surabaya City. Archives of Business Research, 8(1), 138-151.

performance changes toward positive change directions. The results are not parallel with the findings of Sumantri, Fariyanti, and Winandi (2013), in which in the research explained that external influences toward businesswomen business performances are positive and significant.

\section{Business Ethical Influences toward Small Industrial Performances}

Based on the research results, so the finding in this research is business ethics does not have significant influences toward small industrial performances. This case can be seen from the value of $C R$ as 1.101 , by $p$ value as 0.271 or more than 0.05 , it means that the insignificant small industrial performances can be influenced by good business ethics. This case means that the hypothesis that sounds "Business ethics influences toward small industrial performances in Surabaya City" is unaccepted. The analysis results show that business ethics influences insignificantly but it has positive influence directions toward small industrial performances, it means that the better the business ethics owned by small industrial doers in Surabaya, so it will improve and improve the performances owned in running the business. The research results are supported by the research of Ogbari et al (2016) that showed that there are significant relations between business ethical practices and company performances.

\section{Entrepreneurship Orientation Influences toward Small Industrial Performances}

Based on the research results, so the finding in this research is entrepreneurship orientation has significant influences toward small industrial performances. This case can be seen from the value of $C R$ as 2.158 , by $\mathrm{p}$ value as 0.031 or less than 0.05 , it means that small industrial performances can be formed by good entrepreneurship orientation. This case means that the hypothesis that sounds "Entrepreneurship orientation influences toward small industrial performances in Surabaya City" is accepted. The company with high entrepreneurship orientation level will attempt to gain resources prepared by environment. The resources can then be allocated to proactive and innovative project directions that enable the company to explore and exploit chances for changing resources to be superior performances (Rosenbusch, 2013:65). Entrepreneurship orientation tends to have positive implications toward company performances (Setyawati, 2013). The results are parallel with the research results of Sinaga, Mangunwiharjo, and Sugiarto (2016) who found that entrepreneurship orientation influences toward company performances.

\section{Differentiation Strategy Influences toward Small Industrial Performances}

Based on the research results, so the finding in this research is differentiation strategy has significant influences toward small industrial performances. This case can be seen from the value of $C R$ as 2.293 , by $p$ value as 0.022 or less than 0.05 , it means that small industrial performances can be formed by good differentiation strategies. This case means that the hypothesis that sounds "Differentiation strategy influences toward small industrial performances in Surabaya City" is accepted. Purwidianti (2015) stated that business strategies have significant influences toward business performances. The results are not parallel with the findings of Stevanus, Rofiaty, and Aisjah (2016) which also proved that competing strategies do not influence significantly toward company performances.

\section{Competing Superiority Influences toward Small Industrial Performances}

Based on the research results, so the finding in this research is competing superiorities have significant influences toward small industrial performances. This case can be seen from the value of $C R$ as 5.480 , by $p$ value as 0.000 or less than 0.05 , it means that competing superiorities can be formed by good competing superiorities. This case means that the hypothesis that sounds "Competing superiorities influence toward small industrial 
performances in Surabaya City" is accepted. The company that has competing superiorities will have better company performances (Sinaga, Mangunwiharjo, and Sugiarto, 2016). The competing superiority influences and the performances from the research results are also supported by the research results of Sinaga, Mangunwiharjo, and Sugiarto (2016) that showed positive and significant relations between competing superiorities and company performances.

\section{CONCLUSION}

Based on the research results and the discussions in the previous chapter, it can be taken several conclusions in order to answer the problem formulations. The several conclusions consist of:

1. There are influences of internal environmental variable toward differentiation strategy variable in small industries in Surabaya City.

2. There are influences of external environmental variable toward differentiation strategy variable in small industries in Surabaya City.

3. There are influences of business ethical variable toward differentiation strategy variable in small industries in Surabaya City.

4. There are influences of entrepreneurship orientation variable toward differentiation strategy variable in small industries in Surabaya City.

5. There is no influence of internal environmental variable toward competing superiority variable in small industries in Surabaya City.

6. There is no influence of external environmental variable toward competing superiority variable in small industries in Surabaya City.

7. There are influences of business ethical variable toward competing superiority variable in small industries in Surabaya City.

8. There are influences of entrepreneurship orientation variable toward competing superiority variable in small industries in Surabaya City.

9. There are influences of differentiation strategy variable toward competing superiority variable in small industries in Surabaya City.

10. There are influences of internal environmental variable toward small industrial performance variable in small industries in Surabaya City.

11. There is no influence of external environmental variable toward small industrial performance variable in small industries in Surabaya City.

12. There is no influence of business ethical variable toward small industrial performance variable in small industries in Surabaya City.

13. There are significant influences of entrepreneurship orientation variable toward small industrial performance variable in small industries in Surabaya City.

14. There are influences of differentiation strategy variable toward small industrial performance variable in small industries in Surabaya City.

15. There are significant influences of competing superiority variable toward small industrial performance variable in small industries in Surabaya City.

Based on the overall research results and the conclusions achieved, so the suggestions proposed are as follows:

1. It is hoped for Small Industries in Surabaya in order to be able to considerably add feature uniquenesses in each product sold and offered to consumers so it can considerably improve product values compared with other products.

2. It is hoped for Small Industries in Surabaya in order to be more efficient in producting activities and attempt to considerably improve product qualities so it will give impacts in industrial performance improvement.

3. For further researches, it is hoped so that they can use other independent variables assumed to be able to influence big and small industrial performances so it will be 
Tengtarto, J. A. G., Ratnawati, T., \& Kusmaningtyas, A. (2020). Influences Of Internal Environment, External Environment, Business Ethics And Entrepreneurship Toward Business Performances Through Differentiation Strategies And Competing Superiorities In Small Industries In Surabaya City. Archives of Business Research, 8(1), 138-151.

gotten more complete informations upon the factors that can influence differentiation strategies and competing superiorities positively.

\section{References}

Anggraini, F., \& I. P. G. Sukaatmadja. 2015. "Implementasi Strategi Kemitraan, Diferensiasi, Dan Layanan Untuk Meningkatan Kinerja Industri Kuliner Di Kota Denpasar”. E-Jurnal Manajemen Unud, Vol. 4, No. 11, 3991-4018

Coulthard, M. 2007. "The Role of Entrepreneurial Orientation on Firm Performance and the Potential Influence of Relational Dynamism”, Journal of Global Business and Technology, 3,29-39.

Crijns,H. And Ooghi. 2000. Growth Paths of Medium Sized Entrepreneurial Companies. De Vlerick School Voor Management, University of Ghent.

Ferdinand, Augusty. 2003. Sustainable Competitive Advantage: Sebuah Eksplorasi Model Konseptual, Badan Penerbit Universitas Diponegoro, Semarang

Gumelar, G. 2018. Pertumbuhan Industri Kecil dan Mikro Terendah Sejak 2013. Di akses di https://www.cnnindonesia.com/ekonomi/20180201122515-92-273128/pertumbuhan-industri-kecil-dan-mikroterendah-sejak-2013 Pada Senin 08 Januari 2018

Gunawan. 2016. Tahun 2017, Kemenperin Targetkan Pertumbuhan IKM. Di akses di http://www.tribunnews.com/bisnis/2016/12/30/tahun-2017-kemenperin-targetkan-pertumbuhan-ikm pada 30 Desember 2017

Hafsah, M. J. 2003. Kemitraan Usaha: Konsepsi dan Strategi. Pustaka Sinar Harapan. Jakarta.

Handriani, E. 2011. "Pengaruh Faktor Internal Eksternal, Entrepreneurial Skill, Strategi Dan Kinerja Terhadap Daya Saing Ukm Di Kabupaten Semarang". Dinamika Sosial Ekonomi Volume 7 Nomor 1

Ingga. 2009. "Pengaruh lingkungan eksternal, lingkungan internal, strategi kepemimpinan biaya, strategi diferensiasi, terhadap nilai pelanggan dan keunggulan bersaing". Terakreditasi SK Dirjen Dikti No. 43/DIKTI/KEP.

Kotler, P. 2008. Manajemen Pemasaran. Edisi 12 Jilid 2. Jakarta: Indeks

Kuncoro, M. 2006. “Ekonomi Pembangunan”, Penerbit Salemba. Empat, Jakarta.

Mariajie W dan T.Yuniati. 2014. Pengaruh Perilaku Konsumen Terhadap Keputusan Pembelian Compact Disc (CD) di Surabaya. Jurnal Ilmu \& Riset Manajemen. 3 (8) : 1-15

Mulyadi. 2011. Auditing Buku 1. Jakarta: Salemba Empat.

Munizu, M. 2010. Pengaruh Faktor-Faktor Eksternal dan Internal Terhadap Kinerja Usaha Mikro dan Kecil (UMK) di Sulawesi Selatan. Jurnal Manajemen Dan Kewirausahaan, Vol.12, No. 1 hal 33-41

Muslich. 2009. Etika Bisnis Islami. Landasan Filosofis, Normatif, dan substansi Implementatif. Yogyakarta: Ekonisia FE UII.

Nurlina, R., N. Suparta\& N. Sutjipta, 2013. "Lingkungan Internal, Lingkungan Eksternal, dan Orientasi kewirausahaan sebagai Landasan Strategi Diferensiasi, serta Pengaruhnya terhadap Keunggulan Bersaing Usaha Mikro Tanaman Hias di Kota Denpasar". Jurnal Manajemen Agribisnis Vol. 1, No. 2

Nuvriasari, A., G. Wicaksono., \& Sumiyarsih. 2015. Peran Orientasi Pasar, Orientasi Kewirausahaan Dan Strategi Bersaing Terhadap Peningkatan Kinerja UKM

Ogbari, M. E., Adunola, O. O., A. A. Inukunoluwa., M. A. Ajagbe., A. C. Ologbo. 2016. “Entrepreneurship and Business Ethics: Implications on Corporate Performance". International Journal of Economics and Financial Issues, 6 (S3) 5058.

Pearce, J. A., \& Robinson, R. B. 2013. Manajemen Strategis: Formulasi,. Implementasi, dan Pengendalian. Jakarta: Salemba Empat.

Porter, Michael, E. 2008. Strategi Bersaing (Competitive strategy). Tanggerang: Karisma publishing group.

Purwidianti, W., \& T.S.M. Rahayu. 2015. "Pengaruh Faktor Internal Dan Eksternal Terhadap Kinerja Usaha Industri Kecil Dan Menengah Di Purwokerto Utara". KINERJA, Volume 19, No.1, hal. 149-159

Quantananda, E., \& B. Haryadi. 2015. Pengaruh Orientasi. Kewirausahaan Pada Perusahaan Makanan dan Minuman di Surabaya. AGORA Vol 3, No 1 
Ramadhani, D., S. 2012. "Pengaruh Strategi Diferensiasi Terhadap Keunggulan Bersaing (Studi Kasus Pada Konsumen Damarindo Digital Printing di Padang”. Other thesis, Universitas Andalas

Riyanto. S. 2010. "Pengaruh Lingkungan Internal dan Eksternal terhadap Keunggulan Bersaing dan Kinerja Usaha Kecil Menengah (UKM) di Madiun". Jurnal. Universitas PGRI Madiun

Rosenbusch, K. 2013. Effective Leadership. European Journal of Training and Development, Vol. 37, pp. 781-783

Setyawati \& H. Abrilia. 2013. "Pengaruh Orientasi kewirausahaan Dan Orientasi Pasar Terhadap Kinerja Perusahaan Melalui Keunggulan Bersaing Dan Persepsi Ketidakpastian Lingkungan Sebagai Prediksi Variabel Moderasi (Survey pada UMKM Perdagangan di Kabupaten Kebumen)". hlm 20-31.

Sinaga, A.H., S. Mangunwiharjo., \& Sugiarto. 2016. Upaya Peningkatan Kinerja Usaha Mikro Kecil Dan Menengah Melalui Orientasi Kewirausahaan Dan Aset Stratejik Dengan Keunggulan Bersaing Sebagai Variabel Mediasi (Penelitian pada Usaha Mikro Kecil dan Menengah di bidang fashion Kota Semarang). Magister Manajemen, Universitas Diponegoro

Sinaulan, Jeffry H. 2016. "Peran Penting Etika Binsis Bagi Perusahaan-Perusahaan Indonesia dalam Bersaing di Era Masyarakat Ekonomi Asean”. Jurnal Ekonomi Keuangan dan Manajemen, 10(2), 19-32.

Stevanus, V.N., Rofiaty, \& S. Aisjah. 2016. "Faktor Lingkungan Usaha Dan Strategi diferensiasi Terhadap Keunggulan Bersaing Dan Kinerja Usaha (Studi Pada UMKM di Kota Malang)". Media Mahardhika Vol. 15 No. 1

Sulistiani, D. 2014. Mencapai Keunggulan Bersaing Dengan Strategi Diferensiasi. Jurnal. Akuntansi Fakultas Ekonomi. Universitas Islam Negeri Maulana Malik Ibrahim Malang

Sumantri, B., A. Fariyanti, \& R. Winandi. 2013. "Penelitian ini berjudul "Faktor-Faktor yang Berpengaruh terhadap Kinerja Usaha Wirausaha Wanita: Suatu Studi pada Industri Pangan Rumahan di Bogor". Jurnal Manajemen Teknologi. Volume 12 Number 3

Syafarudin. A. 2015. The Influence Of External And Internal Environment On The Competitive Strategy And The Partnership Strategy And Its Impact On The Competitive Advantage And Its Implication On The Performance Of Small And Medium Enterprises In West Sumatra. Jurnal Faculty of Economics and Business University of Padjadjaran.

Thibault, Charlotte. 2001. Gender and Development: Training Kit. Ottawa: Comité québécois femmes et Développement Wood

Thompson, Jr. Arthur. A. \& Strickland, III. A. J., 2010, Crafting and Implementing Strategy : Text and Readings, 10th Edition, McGraw-Hill International Editions, Singapore

Wheelen, Thomas L., Hunger, J. David. 2008. Strategic Management and Business Policy Achieving Sustainability. Twelfth Edition. Pearson

Wulandari, A. 2009. Pengaruh Lingkungan Eksternal Dan Lingkungan Internal Terhadap Orientasi Wirausaha Dalam Upaya Meningkatkan Kinerja Perusahaan. Jurnal Pengembangan Wiraswasta VOL. 11 NO. 2: 142 - 152

Zimmerer, T. W., \& N. Scarborough. 2008. Kewirausahaan dan. Manajemen Usaha Kecil. Jakarta: Salemba Empat 